\title{
Happiness perception in Spain, a SEM approach to evidence from the sociological research center
}

\author{
Estela Núñez-Barriopedro ${ }^{1} \cdot$ Rafael Ravina-Ripoll $^{2} \cdot$ Eduardo Ahumada-Tello $^{3}$ (D)
}

(c) Springer Nature B.V. 2019

\begin{abstract}
In the current study, we examined the relationship between perceived person happiness and factors that influence this perception, also, is inferred that life satisfaction is influence by happiness. Among 2494 Spaniards individuals of both sexes, we found that these individuals valued political situation, economic situation and socio-demographic characteristics to have a strong association in that order, with happiness and that this last construct is a fundamental factor to life satisfaction. The importance of perception is validated using a structural equation model that evaluates relationships and validity on the constructs in question. Collinearity statistics, average variance extracted, and an estimated partial least square regression model are evaluated to confirm independent meaning, correct construct measure and endogenous variable explanation by the predictive constructs. Results indicate that the level of happiness in Spaniards is most influenced by political perception. Theoretical and practical implications of these findings are discussed, and it is proposed to continue this study in a non-developed country.
\end{abstract}

Keywords Happiness · Life satisfaction · Political situation · Economic situation · Sociodemographic characteristics $\cdot$ SEM

Electronic supplementary material The online version of this article (https://doi.org/10.1007/s1113 5-019-00955-w) contains supplementary material, which is available to authorized users.

Eduardo Ahumada-Tello

Eduardo.Ahumada@uabc.edu.mx

Estela Núñez-Barriopedro

estela.nunezb@uah.es

Rafael Ravina-Ripoll

rafael.ravina@uca.es

1 Economy and Business Management, Universidad de Alcalá, Madrid, Spain

2 Business Organization, Universidad de Cádiz, Cádiz, Spain

3 Facultad de Contaduría y Administración, Universidad Autónoma de Baja California, Tijuana, B.C., Mexico 


\section{Introduction}

Studies on happiness have increased in recent years. This emotional perception of life expectancy fulfillment is considered important for employees' performance and to increase firm motivation for the acquisition of skills, competences and strategies for developing competitiveness and productivity through processes of innovation and creativity (RavinaRipoll et al. 2017). That is why studies on this subject become necessary to justify organizational strategies to define and to implement strategic actions aimed at increasing the employee's perception on this issue in all types of companies and recently in knowledgeintensive firms (Salas-Vallina et al. 2018).

The way in which the economic and political situation of a region or country are analyzed and perceived can define the perception and level of happiness of the inhabitants. Happiness in itself, is a concept that has been studied and considered for the establishment of socioeconomic strategies in classic economic models and in modern versions of the enrichment of several countries (Rojas 2016). The perception of satisfaction, state of well-being and happiness that workers in a specific sector have is important for their selfcompetitiveness (Ahumada-Tello 2017). In the same way, these three mentioned concepts have been investigated separately and also as complementary constructs that can be used to describe the workers' level of job stability (Veenhoven 2012).

The main objective of this work is to design a structural equation model that helps to empirically explain the impact of the political situation, the economic situation of a country along with socio-demographic factors on the happiness of citizens, and consequently, in the level of satisfaction with life. This type of study is the first one carried out in Spain using the primary data from the barometers (CIS). This work has been structured in the following sections: in Sect. 2 it has been carried out a review of the relevant literature on the topic of this research and the working hypotheses have been presented. In the following sections the content are: 3 Methodology, 4 Results, 5 Discussion and 6 Conclusions.

This approach to the study of happiness focuses on relating these variables to the influence obtained in the perception of life satisfaction from happiness and develops the following research questions:

1. Does perceived economic situation influences in some degree the perception of happiness in Spaniards population?

2. Does perceived political situation influences in some degree the perception of happiness in Spaniards population?

3. Do socio-demographic characteristics influence in some degree the perception of happiness in Spaniards population?

4. Does happiness influences in some degree life satisfaction in Spaniards population?

\section{Theoretical framework: empirical model, hypothesis development and proposed model}

Throughout the last decades, a significant volume of bibliographic production on the science of happiness indicates that the word happiness is synonymous with the concepts of subjective well-being and quality of life (Salas-Vallina et al. 2018; Ball and Chernova 2008; Tsou and Liu 2001). From this perspective, there is a vast academic literature that explores 
how socio-demographic variables influence the happiness of human beings (MacKerron 2012). Several authors (Frey and Stutzer 2018; Easterlin 2013; Noll 2013; Duncan 2010; De Prycker 2010; Wu and Zhu 2016; Kahneman et al. 2010; Florida et al. 2013) show that countries who develop strong social policies improve the collective happiness of their citizens in today's society. An abundant number of these works, as well as many other empirical studies that analyze the link between political stability and development with happiness and subjective well-being (Otis 2017; Degutis and Urbonavicius 2013; Stanca 2010; Howell and Howell 2008), are characterized by using the surveys prepared by official and private institutions to measure the notion of happiness as a main source of secondary information. Despite this reality, it is worth noting the existence of a recent growth in the corpus of scientific publications that criticize the use of this particular quantitative technique of data collection to measure subjective well-being; it understands that it is an arbitrary, biased and "non-scientific" instrument (Kaminitz 2018; Maridal et al. 2018; Van Praag et al. 2004; Ng 1996).

Parallel to this academic debate, and given the scarcity of economic and sociological work on happiness in Spain (De Juan et al. 2014; Portela Maseda and Neira Gómez 2012; Iglesias et al. 2013), it is necessary to undertake empirical studies that demonstrate the influence of politics and the economy in the happiness of the Spanish people (Peiró 2004), this study was born with two basic goals. On the one hand, to design a structural equation model that empirically explains the influence exerted by the political-economic situation of a country as well as the socio-demographic factors in happiness perception of the Spaniards (Peiró 2004). And on the other, to examine the reflective relationship between the happiness and life satisfaction (Blasco-Belled et al. 2019).

From this double perspective, this line of research can contribute to the emergence of a source of scientific texts that explore whether the implementation of government strategies, aimed at increase sustainable development in Spain, can significantly help to stimulate the quality of life or the social wellbeing of a high proportion of its population (Núñez-Barriopedro et al. 2018a; Ravina-Ripoll et al. 2019). According to the literary review made in the lines above, the following working hypotheses are formulated:

H1 Perceived economic situation has a positive influence on happiness degree of Spaniards.

It is widely accepted by scientific literature that citizens happiness is affected at a macroeconomic level by the productive growth of territories, inflation and per capita income (Helliwell and Huang 2014; Frey and Stutzer 2010; Tella et al. 2003). A wide range of academic product has been devoted to exploring the relationship between GDP and happiness (Núñez-Barriopedro et al. 2018b). Many empirical results show the existence of a positive relation between both parameters in a long-term approach (Chiu and Wong 2018; Mikucka et al. 2017; Bonasia et al. 2017; Hagerty and Veenhoven 2003). According with this research, an extensive number of articles have demonstrated-using metric analysis of information contained in official data, elaboration of econometric models or by designing longitudinal or panel surveys, that the economic situation of the country have an impact on collective and personal happiness, especially when the following factors occur: financial crises, social inequalities, depreciation of wage incomes or degradation of the environment (Akay et al. 2017; Gonza and Burger 2017: Cuñado and De Gracia 2013; MacKerron and Mourato 2013). In the case of Spain, there are a few numbers of scientific contributions that explore from information contained in the survey of the SRC, on how the economic 
situation affects happiness of its inhabitants. For the above, it is considered interesting to raise the following hypothesis:

H1 Perceived economic situation has a positive influence on happiness degree of Spaniards.

H2 Perceived political situation has a positive influence on happiness degree of Spaniards.

Academic interest in exploring the political-happiness construct has notably increased since the late twentieth century to present days (Seung 2018; Bartolini et al. 2016; Layard 2006a, b; Bok 2010; Ng and Ho 2006; Radcliff 2001; Veenhoven 1997). Many of these scientific works reveal, on one hand, that a democratic system that encourages popular initiatives, contributes significantly to improving the collective perception of happiness in citizens (Altman et al. 2017; Loubser and Steenekamp 2017; Graham and Pettinato 2001; Frey and Stutzer 2000; Inglehart and Klingemann 2000). Although, recent studies suggest that there is no strong direct relationship between democracy and subjective well-being of individuals. For Dorn et al. (2008) this fact originates when within the variables of control of social happiness include religion and languages.

And on the other hand, the effective actions of public administrations usually have a positive impact on people happiness, especially in periods of political stability (Hirschauer et al. 2015; Debnath and Shankar 2014; Gholipour Fereidouni et al. 2013; Kim and Kim 2012). In this sense, Ott (2011) shows that average correlation is greater when governments promote a set of legislative measures aimed to increasing per capita income of citizens in a long-term basis and thus reducing socioeconomic inequalities. According to these arguments, the following working hypothesis is formulated.

H2 Perceived political situation has a positive influence on happiness degree of Spaniards.

H3 Socio-demographic factors have a positive influence on happiness degree of Spaniards.

An extensive academic production of theoretical and statistical nature estimates that personal happiness does not depend exclusively on economic and political situation of territories but also on other multiple elements of different nature. Take socio-demographic factors as an example (Gudmundsdóttir et al. 2016; Rojas 2016; Dolan et al. 2008; Gerdtham and Johannesson 2001); among them, the following variables can be highlighted: gender, age, marital status, education or employment situation. A literature review regarding how demographic factors cited above have an impact on people happiness shows us that: (1) happiness is not constant throughout the human being's life (Graham and Ruíz 2017; Frijters and Beatton 2012); (2) women are happier than men (Arrosa and Gandelman 2016; Zweig 2015); (3) the conjugal status variable positively affects individual happiness (Carr et al. 2014; Waite and Lehrer 2003); (4) the educational level does not have a direct impact on happiness in inhabitants of the most advanced countries (Cuñado and De Gracia 2012; Argyle 2003); and (5) unemployment generates social and emotional unhappiness (Ruprah and Luengas 2011; Clark and Oswald 1994).

Focusing on the spatial framework of this study, it is appropriate to point out that the lack of economic research that uses as a primary source the data offered by surveys of the Sociological Research Center (SRC) to analyze the influence of socio-demographic factors on the happiness Spanish people encourages this investigation. Based on this argument and 
the work carried out by Ahn and Mochón (2010), it is considered interesting to propose the following hypothesis:

H3 Socio-demographic factors have a positive influence on happiness degree of Spaniards.

H4 Happiness influences life satisfaction of the Spaniards.

In the literature there is a first approach of scientific works that considers subjective wellbeing and life satisfaction as a synonym of happiness (Myers and Diener 1995; Diener 2000; Layard 2006a, b). This classic approach has evolved by highlighting the contributions of other authors who define the concept of happiness as a set of emotions and experiences of a hedonic or eudaimonic nature that are directly influenced by having a satisfied life and with a great number of achievements (Haybron 2007; Lane 2000). Gundelach and Kreiner (2004) affirm that "happiness and life satisfaction are related but are different concepts and that contextual as well as individual variables are important in explaining their variations". This idea is also defended by works currently (Cortés Sierra et al. 2019). In this sense, Haybron (2007) and Abdel-Khalek (2006) point out the existence of a strong statistical correlation between both variables. This last author demonstrates it empirically by using the Oxford happiness scale (OHS) (Hills and Argyle 2002) and the Satisfaction with Life Scale (SWLS) (Pavot and Diener 1993).

According to this principle there is a wide variety of scholars that examines, from different points of view and academic disciplines, the relationship between the variables life satisfaction and happiness (Ngamaba and Soni 2017; Botha and Booysen 2014; Peterson et al. 2013; Proctor et al. 2010; Marinić and Brkljačić 2008). These investigations try to deepen the knowledge on this construct from statistical analysis of variables defined as personal, economic and social nature that act as potential predictors to the relationship between life satisfaction and happiness. So, it is not surprising, that many of the findings obtained in recent years suggest that individuals who are happier are satisfied with their lives (Peiró 2006; Veenhoven 2012; Ravina-Ripoll et al. 2017; Husser and Fernández 2018; Gamble and Gärling 2012; Ahumada-Tello 2017).

On the basis of the literature reviewed, it is reasonable to affirm the existence of a limited scientific production regarding this topic in studies performed in Spain unlike other European territories (Selim 2008; Gundelach and Kreiner 2004). Given these circumstances, it is interesting to empirically justify if the dominant academic reference on the direct association between life satisfaction and happiness is also fulfilled in Spain. As a result of the above is stated the next hypothesis:

H4 Happiness influences life satisfaction of the Spaniards.

\section{Methodology}

This work is based on a co-relational empirical study by means of a survey obtained from the primary data from the barometers of the SRC, whose sample size is 2494 individuals of both sexes. The sampling procedure has been multistage, stratified by conglomerates, with a selection of the primary sampling units (municipalities) and of the secondary units (sections) in a proportional random manner, and a selection of the last units (individuals) by random routes and quotas of sex and age. 
The strata have been formed by crossing the 17 autonomous communities, with the size of the habitat, divided into 7 categories: less than or equal to 2000 inhabitants; from 2001 to 10,000 ; from 10,001 to 50,000 ; from 50,001 to 100,000 ; from 100,001 to 400,000 ; from 400,001 to 1000,000 and more than 1000,000 inhabitants. The questionnaires have been applied through a personal interview at home in 253 municipalities and 48 provinces.

The sample error for a confidence level of $95.5 \%$ (two sigmas), and $\mathrm{P}=\mathrm{Q}$, the real error is $\pm 2.0 \%$ for the whole sample and in the assumption of simple random sampling. The date of completion of the last wave corresponds to September 2017. This work takes Spain as the geographical area of study. The main objective of this research is to analyze a structural model in which the main economic, political and socio-demographic variables that influence happiness are examined. In this way, it can be determined in which variables that happiness is reflected. You can find the model formulated in this article in Fig. 1.

The Structural Equation Model (SEM) combines the use of constructs that represent the concepts of theory, and data that come from measurements (items) that are used as inputs for a statistical analysis that provides evidence about the relationships between latent variables (Williams, Vandenberg and Edwards 2009).

Since the observed variables used are of a formative and reflective nature, the partial least squares (PLS) approach has been applied for the estimation of the designed model (Chin 1998; Chin and Newsted 1999). The SmartPLS program has been used for this purpose (Ringle et al. 2015)

Table 1 details the latent variables together with the manifest variables or model item.

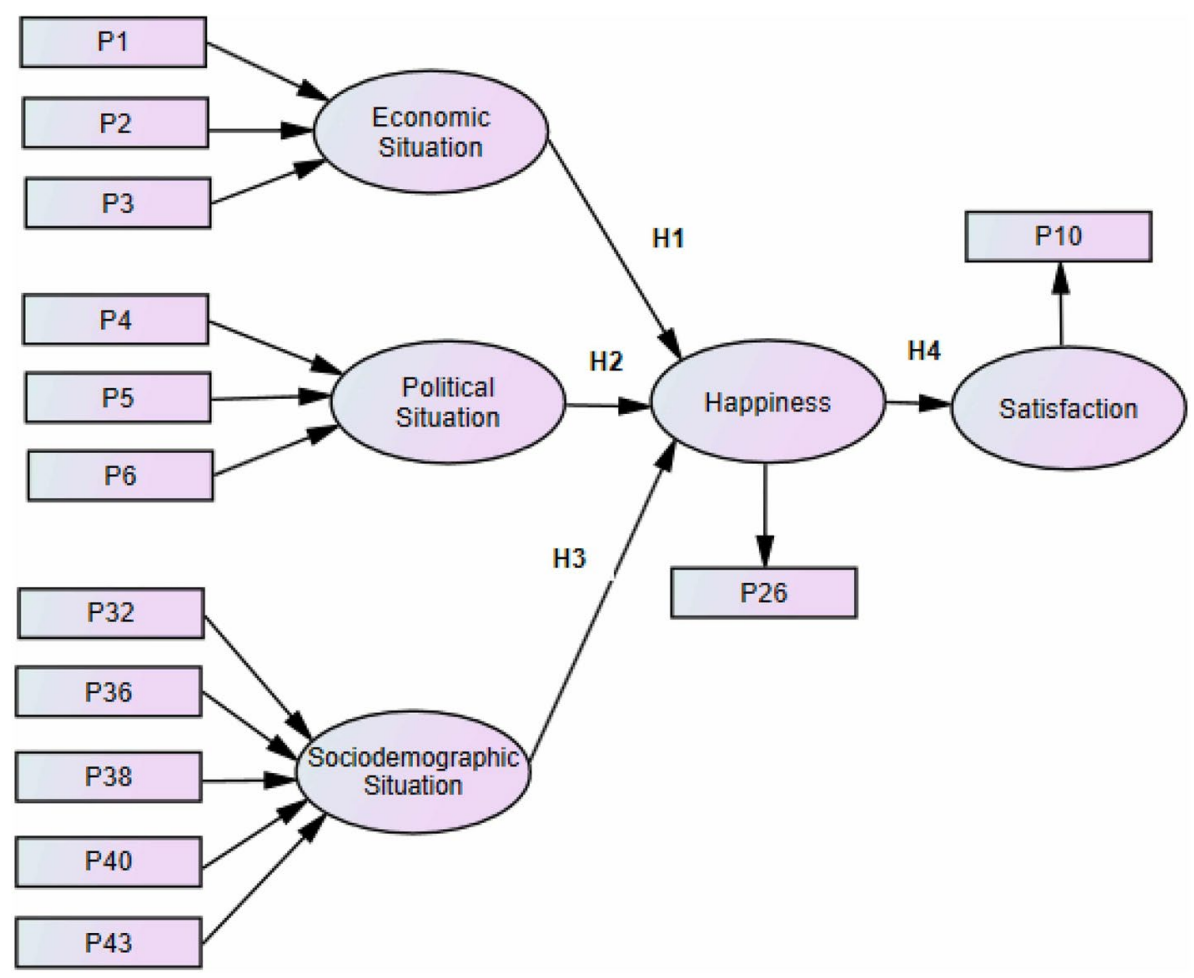

Fig. 1 Theoretical model proposed. Source: Own elaboration 
Table 1 Latent and manifest variables of the structural equation model. Source: Own elaboration

\begin{tabular}{lll}
\hline Constructs & Items & Content \\
\hline Economic situation & P1 & Economic situation in Spain \\
& P2 & Current economic situation in Spain is better, equal or worse than last year \\
& P3 & Future economic situation in Spain in 1 year will be better, equal or worse \\
Political situation & P4 & Political situation in Spain \\
& P5 & Current political situation in Spain is better, equal or worse than last year \\
Sociodemographic & P32 & Sex \\
characteristic & & \\
& P36 & Personal economic situation \\
& P38 & Marital status \\
Satisfaction & P40 & Labor status \\
Happiness & P43 & Economic sector activity \\
\hline
\end{tabular}

This study examines the relationship between five latent variables or constructs (see Table 1). There are three dimensions that explain the Happiness construct, called Economic situation, Political Situation and Sociodemographic Characteristic. The SRC questionnaires and their items have allowed measuring the five different latent constructs: Happiness (a second order construct with three dimensions), Economic Situation (explained by three items, P1, P2 and P3), Political Situation (explained by three items), P4, P5 and P6), and Sociodemographic Characteristic (explained by five items, P32, P36, P38, P40 and P43).

According to the scale of measurement, items P1 and P4 are valued by a Likert scale of 5 points (being 1 Very good and 5 Very bad). On the other hand, items P2, P3, P5 and P6 are rated on a scale of 3 points (1. Better, 2. Equal and 3. Worse).

Likewise, the latent Happiness variable is a reflection of the level of happiness, which is reflected in item P26, whose observed variable is "Personal happiness scale", measured on a scale of 1-10, as well as Happiness influences the satisfaction that is reflected in item P10, whose observed variable is metric, "Level of satisfaction with your life in general" measured on a scale of $1-10$.

\section{Results}

\subsection{Model assessment}

The measurement model in the PLS is valued in terms of the inter-construct correlations, the correlations between items, the Cronbach's alpha, and the reliability and the average of the variance extracted for each construct (AVE). In this case, the five latent variables (one of them a second-order construct) are composed of scales with formative and reflective items. The following lines assess the measure of reliability, internal consistency and 


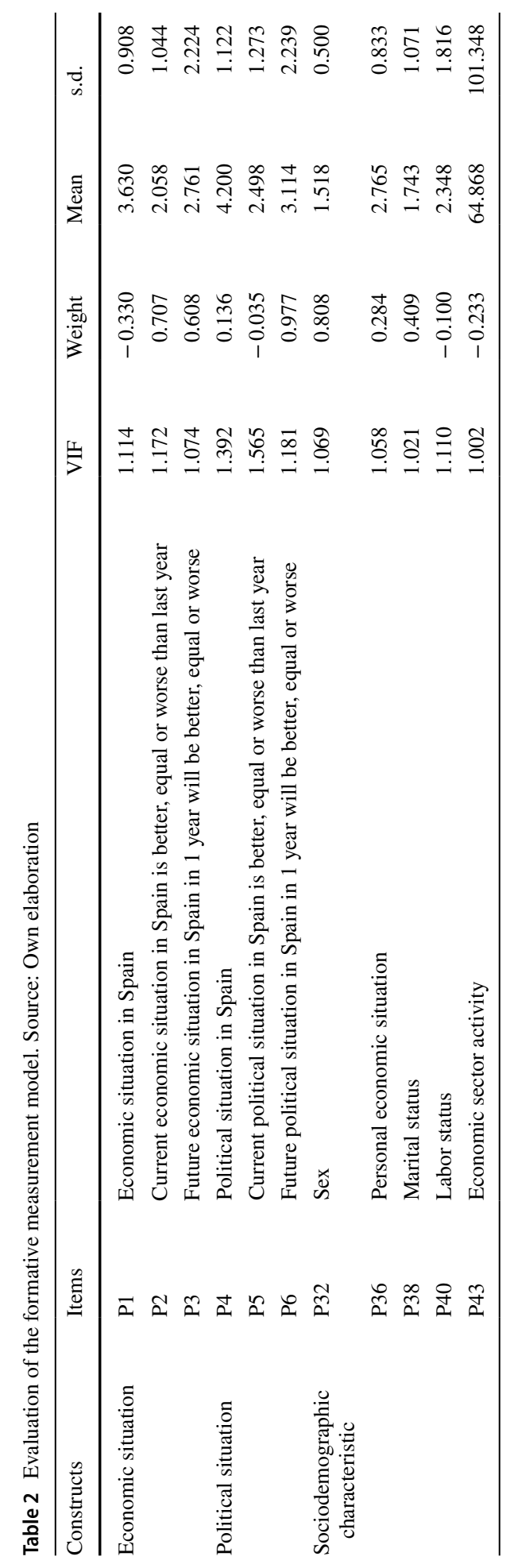


discriminant validity for each of the components of happiness and the variables in which happiness is reflected.

Firstly, the formative measurement model is evaluated. For this, the collinearity statistics (VIF) is observed in Table 2. It can be verified that all the items show values $<3.3$, so there are no problems of collinearity.

With respect to the weights, the variable that most explains the economic situation is the current economic situation related to the past situation (item P2), followed by the future economic situation within a year (item P3) and finally the general economic situation, which is somewhat pessimistic (item P1). In relation to the political situation, the scenario remains pessimistic, although the variable that best shapes it is the expectation of the political situation within a year (P6), since it is worse valued than the previous year (P5).

Another interesting idea that the model points out, is to be able to assess different economic situations over time as an indicator, so the results implied in their meanings and in the weight that while past (P2) and future economic growth positively influence happiness (P3), the general economic situation in Spain (P1) affects negatively and this may be due to economic and social crisis situation at the time the survey was conducted in this country.

From the political situation, interesting ideas are also analyzed when measuring this variable with items corresponding to different temporal contexts. Thus, the past political situation creates discomfort (P5) while the future hope of a better political situation (P6) positively influences and weighs heavily on happiness. For its part, the general political situation in Spain (P4) positively influences happiness but weighs lower than the political hope which has a very strong weight.

Regarding the weights of the socioeconomic variables, what weighs the most is gender (P32), followed by civil status (P38), personal economic situation (P36), sector of activity (P43) and employment status (P40). On the other hand, both the level of happiness (average 8.22) and the satisfaction of life in general (average 8.08) of Spanish people have an average score of 8.15 but with high values of dispersion (see Table 3).

Regarding the reflective model (Table 3), to assess reliability we examine to what extent each item is related to the latent construct. In this sense, the most accepted and widespread empirical rule is that proposed by Carmines and Zeller (1979), who point out that, in order to accept an indicator as a member of a construct, it must have a load equal to or greater than 0.707 .

Thus, as shown in the model evaluation (see Table 3), item P10 Satisfaction with life is a good indicator of the satisfaction construct and the value of its Load is 0.852. On the other hand, the happiness construct is reflected in item P26 Personal happiness scale since the value of its Load is 0.764 . So, this model focuses on the personal happiness of the Spanish.

On the internal consistency, two measures are valued, the Cronbach's alpha and the compound reliability. Nunally (1978) suggests 0.7 as a level for acceptable reliability. Both indicators exceed the value of 0.7 .

Table 3 Evaluation of the reflective measurement model. Source: Own elaboration

\begin{tabular}{lllllll}
\hline Constructs & Items & & VIF & Load & Mean & s.d. \\
\hline Satisfaction & P10 & Satisfaction with life scale & 1.109 & 0.852 & 8.083 & 5.675 \\
Happiness & P26 & Personal happiness scale & 1.109 & 0.764 & 8.224 & 6.233 \\
\hline
\end{tabular}


Table 4 Correlation and square root of the AVE of first order latent construct. Source: Own elaboration

Economic situ- Happiness Political situation Sociodemoation graphic characteristic

\begin{tabular}{|c|c|c|c|c|}
\hline Economic situation & 0.821 & & & \\
\hline Happiness & 0.067 & 0.809 & & \\
\hline Political situation & 0.371 & 0.082 & 0.841 & \\
\hline $\begin{array}{l}\text { Sociodemographic char- } \\
\text { acteristic }\end{array}$ & 0.062 & 0.054 & 0.099 & 0.784 \\
\hline
\end{tabular}

Table 5 R square and StoneGeisser Source: Own elaboration

\begin{tabular}{lll}
\hline & $\mathrm{R}^{2}$ & $\mathrm{Q}^{2}$ \\
\hline Economic situation & 0.29 & 0.27 \\
Political situation & 0.55 & 0.49 \\
Sociodemographic characteristic & 0.22 & 0.17 \\
\hline
\end{tabular}

The results in Table 3 indicate that satisfaction with the general life of the Spaniards is quite remarkable (mean 8.083) although it should be noted that there is a considerable dispersion of opinions (5.675). Likewise, the scale of happiness of the Spaniards is also quite remarkable (mean 8.224) with a wide dispersion of opinions. These results show a realistic scenario as a large sample is that of this study with 2494 individuals from 17 different autonomous communities.

The validity of the discriminant is obtained by means of two paths. In the first one, the average variance extracted (AVE) is examined. These values must exceed 0.50 (Fornell and Larcker 1981). In this work, all values of AVE are higher than the indicated value. In the second one, the square roots of AVE (on the diagonal of Table 4) are compared with that of the rest of the constructs (below the diagonal in Table 4). These statistics suggest that each construct is stronger in its own measure than in the measure of another construct.

Statisticians suggest that the components of our measurements are reliable, are internally consistent and have discriminant validity.

\subsection{Model assessment}

An estimated model by means of the PLS allows us to determine the amount of the variance of the endogenous variables explained by the constructs that predict them. Falk and Miller (1992) point out that the explained variance of the endogenous variables $\left(\mathrm{R}^{2}\right)$ should be greater than or equal to 0.1 . In relation to this model, the indexes relatively explain a great amount of variance of Happiness since the $\mathrm{R}^{2}$ values are $0.29,0.55$ and 0.22 for the Economic Situation, Political Situation and Sociodemographic Characteristic dimensions respectively. In addition, the Stone-Geisser statistic $\left(\mathrm{Q}^{2}\right)$ is greater than zero, which indicates that the model has predictive relevance. The Stone-Geisser statistics $\left(\mathrm{Q}^{2}\right)$ are 0.27 , 0.49 and 0.17 for the latent variables Economic Situation, Political Situation and Sociodemographic Characteristic respectively (Table 5). 


\section{Discussion}

The relevance of a study on perceptions in emotional issues is especially important when this perception influences other attitudes and actions that individuals may or may not develop. From the degree of life satisfaction in individual terms to their participation in productive processes that have a detrimental influence on the economic and competitive development of a geographical region or an industrial, service or educational sector or environment.

This paper addresses specific approaches on the political, economic and socio-demographic characteristics of the Spanish population and how they influence the perception of happiness and the consequently of life satisfaction. To meet the objectives of finding the answer the research questions, where the search for influence between the factors mentioned at the beginning of this paragraph is considered, an analysis of the data obtained in the SRC is carried out on a sample of the Spanish population and the values obtained are contrasted through the selection of items that define the proposed analyzed variables.

To carry out this analysis, we propose a model that represents the relationship between the variables illustrated in Fig. 1 as a basic approach to research. Part of the result validates the hypotheses raised and that are mentioned individually in the next paragraphs.

H1 Perceived economic situation has a positive influence on happiness degree of Spaniards.

In this aspect, the results indicate that the influence of economic perception in the sense of happiness is positive. For this purpose, the AVE is carried out with a value of 0.821 with its own construct that is above the one of the other factors and is therefore validated. Then, the square $\mathrm{R}$ and the Stone-Geisser indicator indicate the percentage of the variance of the endogenous variable explained by the construct, in this case the economic situation [0.27] and the predictive relevance of this construct on happiness is validated [0.27]. These results confirm the importance of perceived economic situation on the develop of happiness in persons (Helliwell and Huang 2014; Frey and Stutzer 2010; Di Tella et al. 2003).

H2 Perceived political situation has a positive influence on happiness degree of Spaniards.

The results indicate that the influence of political perception in the sense of happiness is positive. For this the AVE is carried out with a value of 0.841 with its own construct that is above the other factors shared and therefore is validated. Next, the square $\mathrm{R}$ and the Stone-Geisser indicator indicate the percentage of the variance of the endogenous variable explained by the construct, in this case the political situation [0.55] and the predictive relief of this construct on happiness is validated [0.49]. These results indicate that to a large extent, for Spaniards, the political situation determines with greater impact the perception of happiness and life satisfaction. The work of several previous authors is confirmed (Frey and Stutzer 2018; Easterlin 2013; Noll 2013; Duncan 2010; De Prycker 2010) as to the relation between politics-happiness is one of the most relevant to increase life satisfaction. Nevertheless, its confirmed too that political stability is important to people and a great challenge to governments (Hirschauer et al. 2015; Debnath and Shankar 2014; Gholipour Fereidouni et al. 2013; Kim and Kim 2012).

H3 Socio-demographic factors have a positive influence on happiness degree of Spaniards. 
The results indicate that the influence of socio-demographic factors in the sense of happiness is positive. To do this, the AVE is carried out with a value of 0.784 with its own construct that is above the one of the other factors and is therefore validated. Next, the square $\mathrm{R}$ and the Stone-Geisser indicator indicate the percentage of the variance of the endogenous variable explained by the construct, in this case the economic situation [0.22] and the predictive relief of this construct on happiness is validated [0.17]. Given these results, this construct is the one with the lowest level of influence against the construct of happiness but confirms its importance in the develop of life satisfaction (Gudmundsdóttir et al. 2016; Rojas 2016; Dolan et al. 2008; Gerdtham and Johannesson 2001; Graham and Ruíz 2017; Frijters and Beatton 2012).

H4 Happiness influences life satisfaction.

Happiness is part of the lives of people, before this indicator, it is inferred that life satisfaction is associated with perception from a positive relational approach. Because individuals perceive a stable economic situation and with expectations of improvement, greater protection from the political environment and less representative influence by socio-demographic factors, it is then possible to affirm that the data referring to sex, marital status among others that make up the profile of the sample studied, are not determinants of happiness at the same level as the perception of economic improvement and political stability and (Ngamaba and Soni 2017; Botha and Booysen 2014; Peterson et al. 2013; Proctor et al. 2010; Marinić and Brkljačić 2008), but it is presumed that these findings suggest that individuals who are satisfied with their life are happier as expected (Peiró 2006; Veenhoven 2012; Ravina-Ripoll et al. 2017; Husser and Fernández 2018; Gamble and Gärling 2012; Ahumada-Tello 2017).

These findings increase and nurture literature in two ways. The first from regional perspectives in areas that address economic, political and socio-demographic approaches. This focuses specifically on people who, while assessing their own perception of happiness, also analyze personal situations in terms of the independent variables that analyze the established problem. This increases the knowledge that we have about the Spanish population in the sense of triggers and restrictors of perceived happiness.

The second is established in the sense of using mathematical studies through the use of structural equations to confirm the theoretical models that arise when using SRC information. These studies confirm the hypotheses raised and therefore meet the objective of the research to complete the study and answer the research questions indicated in this paper that focus on the influence of the perception of economic situation and political situation, as well as the sociodemographic factors that are analyzed from information concentrated in the observatory.

Although the elements that make up this research are treated independently, in a certain way it is observed that the relationship between them is not fully identified as causal, but rather as a kind of integral approach in the social field. For the determination of the benefit of doing studies of happiness in spaces where data are not accessible in a natural way, but are immersed in political, economic and social complexity, it is necessary to continue and confirm these findings in spaces different from those of a developed country. These points of views on concepts and constructs detonators of the perception of purpose, may not be generalizable, without not having to maintain a comprehensive vision that considers the different realities in which people live to confirm whether the independent variables studied are equally important in third world countries or even from another develop country. 


\section{Conclusions}

In this research, the analysis of the constructs of economic perception, policies and sociodemographic characteristics that have an impact on the perception of happiness is carried out. The approach is based on previous studies aimed at giving the strategic importance to people perception of their personal happiness construct based on the previously mentioned independent variables. In this study we find important relationships in the variable of perception of political situation and happiness based on better living conditions (Ott 2011), this is presented as the most relevant factor for Spaniards in terms of construction of a thought scheme that defines the importance to which it is made mention to increase the possibility of a better sense of life satisfaction (Hirschauer et al. 2015; Debnath and Shankar 2014).

The individuals participating in this survey ratify the hypotheses and prove evident that educational, labor and government organizations consider political and economic stability as fundamental axes for a sense of satisfaction that has multiple benefits in the members of a social group (Cuñado and De Gracia 2012; Argyle 2003). Happiness in itself increases the competitiveness of the individuals that consequently also modify the organizational competitiveness in the companies where they are working (Ahumada-Tello 2017). Happiness is part of life satisfaction, the elements that build a greater perception on happiness, often also cause an increase in the latter. It is necessary that at the organizational level, strategic changes are carried out in the development of plans that improve the motivation of the members of a social, labor or educational group so that, in turn, this sense of improvement in the quality of life is a an approach that improves the economic, political and social conditions of the members of the community (Peiró 2006; Veenhoven 2012; Ravina-Ripoll et al. 2017, 2018; Husser and Fernández 2018; Ahumada-Tello 2017).

The main reason to perform this research is to develop a model that illustrates the relationship between variables from a triple perspective: (1) economic (variables P1, P2 and P3); (2) politics (variables P4, P5 and P6) and; (3) sociodemographic (P32, P36, P38, P40 and P43) that influence the happiness of the Spaniards as well as see in which variables this happiness is reflected (satisfaction with life in general (P10) and scale of personal happiness (P26)).

Previous studies have analyzed the variables that influence happiness from one of these perspectives partially but one of the novelties of this study is the conjunction of this triple perspective. As well as the analysis of the economic and political dimensions at different times, specifically in the past (P2 and P5), present (P1 and P4) and future (P3 and P6) variables.

Regarding the variable economic situation, the most significant results are the average consideration that the economic situation is the same as a year ago with a somewhat pessimistic expectation for the recent future. This economic stability contributes positively to the degree of happiness of the Spaniards, so hypothesis 1 is accepted: "H1: Perceived economic situation has a positive influence on happiness degree of Spaniards". These results contribute to the same line of research that several previous works have been developed (Chiu and Wong 2018; Mikucka et al. 2017; Bonasia et al. 2017; Hagerty and Veenhoven 2003).

With respect to the variable political situation, the most significant result is the average understanding that the political situation is the same as a year ago with a rather pessimistic expectation for the recent future. This political perception contributes positively to the degree of happiness of the Spaniards, so hypothesis 2 is accepted. "H2: Perceived 
political situation has a positive influence on happiness degree of Spaniards". Therefore, these results contribute to the literature along with previous works on the matter (e.g. Liu et al. 2019; Pacek et al. 2019; Stadelmann-Steffen and Vatter 2012).

According to the analysis of socio-demographic factors, the most significant results show four aspects. The first, that gender has a strong influence on the degree of happiness, being women happier than men. The second, unemployment has a negative effect on happiness, in this matter, it's important to highlight that this work has detected that one of the happiest groups in Spanish society are retired people. The third, that the marital status and the sector of activity in which they work positively affect the happiness of the Spaniards. Therefore, hypothesis 3 is accepted. "H3: Socio-demographic factors have a positive influence on happiness degree of Spaniards". This finding confirms the literature review consulted for the development of this article (Deiana and Mazzarella 2019; Iceland and Ludwig-Dehm 2019; Lawrence et al. 2019; Hori and Kamo 2018; Fukuda 2013: Mookerjee and Beron. 2005).

In relation to happiness reflective variables, it should be noted that both variables, both the level of personal happiness, and the satisfaction of life in general of the Spanish have an average rating of remarkable. Likewise, as can be seen in Table 3 and in Fig. 1, happiness variable and satisfaction variable are different in the sense that the latent happiness variable, from the perspective of personal happiness, is reflected in the latent satisfaction variable, specifically in satisfaction with life in general. Therefore, this is one of the unpublished contributions of this work. So, hypothesis 4 can be accepted. "H4: Happiness influences life satisfaction of the Spaniards". As with the hypotheses previously analyzed, the result achieved in $\mathrm{H} 4$ is equivalent with findings reached in other academic papers (Shin 2019; Argan et al. 2018; Cortés Sierra et al. 2019; Joshanloo et al. 2016; Park et al. 2009).

One of the limitations of this study may be that this triple perspective of economic, political and sociodemographic explanatory variables can be considered and expanded in future studies with new explanatory perspectives. In this regard we must say that in the first approaches of the model other possible variables from the CIS barometer were considered but because their contribution to the model was not significant for this period they were discarded. Likewise, two reflective variables, satisfaction with life in general (P10) and personal happiness scale (P26) are considered. Other variables of the SRC barometer (such as satisfaction with their family life, satisfaction with their free time, satisfaction with their health, satisfaction with their friends and satisfaction with their relationship) were omitted because they were not significant in the model.

Another limitation to the study may be the consideration of a transverse and nonlongitudinal model. In this work it has been considered more appropriate to analyze the explanatory and reflective variables that influence and are the result of happiness for the 2017 SRC barometer data because it is a moment of certain political and economic stability in Spain. However, a longitudinal model has not been considered adequate because possible political events such as those that occurred throughout 2018 can draw another scenario more typical of another type of study in which the political dimension is studied under other items and for different purposes.

Despite the above limitations, the present work explains the proposed model both in the measurement model in which the relationships between latent variables and their indicators are measured as well as in the structural model. This provides a model that proposes relationships between latent variables indicated in each hypothesis and allows contributing to the development of the literature. 
Finally, it is important to highlight that this research has been carried out in a developed country, in future applications it should be considered to carry out this study in less favored environments, in underdeveloped countries and also include other variables that improve the prediction of the model on the studied construct.

\section{Compliance with ethical standards}

Conflict of interest Authors declare there's no conflict of interest.

\section{References}

Abdel-Khalek, A.M.: Measuring happiness with a single-item scale. Soc. Behav. Personal. Int. J. 34(2), 139-150 (2006)

Ahn, N., Mochón, F.: La felicidad de los españoles: factores explicativos. Revista de economía aplicada 18(54), 5-31 (2010)

Ahumada-Tello, E.: Perception of personal competitiveness. A study from the perspective of happiness, well-being and education in university graduates. Revista de Estudios Empresariales Segunda Epoca 1, 34-54 (2017)

Akay, A., Bargain, O., Zimmermann, K.F.: Home sweet home? Macroeconomic conditions in home countries and the well-being of migrants. J. Hum. Resour. 52(2), 351-373 (2017)

Altman, D., Flavin, P., Radcliff, B.: Democratic institutions and subjective well-being. Polit. Stud. 65(3), 685-704 (2017)

Argan, M., Argan, M.T., Dursun, M.T.: Examining relationships among well-being, leisure satisfaction, life satisfaction, and happiness. Int. J. Med. Res. Health Sci. 7(4), 49-59 (2018)

Argyle, M.: Causes and correlates of happiness. In: Kahneman, D., Diener, E., Schwarz, N. (eds.) WellBeing: The Foundations of Hedonic Psychology, pp. 353-373. Russell Sage Foundation, New York (2003)

Arrosa, M.L., Gandelman, N.: Happiness decomposition: female optimism. J. Happiness Stud. 17(2), 731756 (2016)

Ball, R., Chernova, K.: Absolute income, relative income, and happiness. Soc. Indic. Res. 88(3), 497-529 (2008)

Bartolini, S., Bilancini, E., Porta, P.L. (eds.): Policies for Happiness. Oxford University Press, New York (2016)

Blasco-Belled, A., Rogoza, R., Torrelles-Nadal, C., Alsinet, C.: Emotional intelligence structure and its relationship with life satisfaction and happiness: new findings from the bifactor model. J. Happiness Stud. (2019). https://doi.org/10.1007/s10902-019-00167-x

Bok, D.: The Politics of Happiness: What Government Can Learn from the New Research on Well-Being. Princeton University Press, New Jersey (2010)

Bonasia, M., Napolitano, O., Spagnolo, N.: Happy PIIGS? J. Happiness Stud. 19(6), 1763-1782 (2017). https://doi.org/10.1007/s10902-017-9873-y

Botha, F., Booysen, F.: Family functioning and life satisfaction and happiness in South African households. Soc. Indic. Res. 119(1), 163-182 (2014)

Carmines, E.G., Zeller, R.A.: Reliability and Validity Assessment, vol. 17. Sage publications, London (1979)

Carr, D., Freedman, V.A., Cornman, J.C., Schwarz, N.: Happy marriage, happy life? Marital quality and subjective well-being in later life. J. Marriage Fam. 76(5), 930-948 (2014)

Chin, W.W.: Commentary: issues and opinion on structural equation modeling. MIS Q. 22(1), 7-16 (1998)

Chin, W.W., Newsted, P.R.: Structural equation modeling analysis with small samples using partial least squares. Stat. Strateg. Small Sample Res. 1(1), 307-341 (1999)

Chiu, S.W.K., Wong, K.T.W.: Happiness of Hong Kong youth from 2000 to 2014: empirical evidence on the differential impact of socioeconomic conditions on youth versus other age groups. J. Youth Stud. 21(3), 253-271 (2018)

Clark, A.E., Oswald, A.J.: Unhappiness and unemployment. Econ. J. 104(424), 648-659 (1994) 
Cortés Sierra, M.A.G., Delgado Rodríguez, M.J., Ortega Gil, M.: Happiness, territory and sustainable wellbeing in the OCDE countries. In: A Lighthouse from Social Wellbeing, Creativity and Sustainability: Happiness Management. Editorial Peter Lang (2019)

Cuñado, J., De Gracia, F.P.: Does education affect happiness? evidence for Spain. Soc. Indic. Res. 108(1), 185-196 (2012). https://doi.org/10.1007/s11205-011-9874-x

Cuñado, J., De Gracia, F.P.: Environment and happiness: new evidence for Spain. Soc. Indic. Res. 112(3), 549-567 (2013)

De Juan, R., Mochón, F., Rojas, M.: Expectations and happiness: evidence from Spain. J. Soc. Res. Policy 5(2), 101-114 (2014)

De Prycker, V.: Happiness on the political agenda? PROS and CONS. J. Happiness Stud. 11(5), 585-603 (2010)

Debnath, R.M., Shankar, R.: Does good governance enhance happiness: a cross nation study. Soc. Indic. Res. 116(1), 235-253 (2014)

Degutis, M., Urbonavicius, S.: Determinants of subjective wellbeing in Lithuania. Eng. Econ. 24(2), 111-118 (2013)

Deiana, C., Mazzarella, G.: Does the road to happiness depend on the retirement decision? Evidence from Italy. In: Crato, N., Paruolo, P. (eds.) Data-Driven Policy Impact Evaluation: How Access to Microdata is Transforming Policy Design, pp. 237-248. Springer, Cham (2019)

Diener, E.: Subjective well-being: the science of happiness and a proposal for a national index. Am. Psychol. 55(1), 34-43 (2000)

Dolan, P., Peasgood, T., White, M.: Do we really know what makes us happy? A review of the economic literature on the factors associated with subjective well-being. J. Econ. Psychol. 29(1), 94-122 (2008)

Dorn, D., Fischer, J.A., Kirchgässner, G., Sousa-Poza, A.: Direct democracy and life satisfaction revisited: new evidence for Switzerland. J. Happiness Stud. 9(2), 227-255 (2008)

Duncan, G.: Should happiness-maximization be the goal of government? J. Happiness Stud. 11(2), 163$178(2010)$

Easterlin, R.A.: Happiness, growth, and public policy. Econ. Inq. 51(1), 1-15 (2013)

Falk, R.F., Miller, N.B.: A Primer for Soft Modeling. The University of Akron Press, Akron (1992)

Florida, R., Mellander, C., Rentfrow, P.J.: The happiness of cities. Reg. Stud. 47(4), 613-627 (2013)

Fornell, C., Larcker, D.: Evaluating structural equation models with unobservable variables and measurement error. J. Mark. Res. 18(1), 39-50 (1981). https://doi.org/10.2307/3151312

Frey, B.S., Stutzer, A.: Happiness prospers in democracy. J. Happiness Stud. 1(1), 79-102 (2000)

Frey, B.S., Stutzer, A.: Happiness and Economics: How the Economy and Institutions Affect Human Well-Being. Princeton University Press, New Jersey (2010)

Frey, B.S., Stutzer, A.: Economics of Happiness. Springer, Cham (2018)

Frijters, P., Beatton, T.: The mystery of the U-shaped relationship between happiness and age. J. Econ. Behav. Organ. 82(2-3), 525-542 (2012)

Fukuda, K.: A happiness study using age-period-cohort framework. J. Happiness Stud. 14(1), 135-153 (2013)

Gamble, A., Gärling, T.: The relationships between life satisfaction, happiness, and current mood. J. Happiness Stud. 13(1), 31-45 (2012)

Gerdtham, U.G., Johannesson, M.: The relationship between happiness, health, and socio-economic factors: results based on Swedish microdata. J. Socio Econ. 30(6), 553-557 (2001)

Gholipour Fereidoni, H., Nadji, Y., Ekhtiari Amiri, R.: Do governance factors matter for happiness in the MENA region? Int. J. Soc. Econom. 40(12), 1028-1040 (2013)

Gonza, G., Burger, A.: Subjective well-being during the 2008 economic crisis: Identification of mediating and moderating factors. J. Happiness Stud. 18(6), 1763-1797 (2017). https://doi.org/10.1007/s1090 2-016-9797-y

Graham, C., Pettinato, S.: Happiness, markets, and democracy: Latin America in comparative perspective. J. Happiness Stud. 2(3), 237-268 (2001)

Graham, C., Ruíz, Pozuelo J.: Happiness, stress, and age: how the U curve varies across people and places. J. Popul. Econ. 30(1), 225-264 (2017)

Gudmundsdóttir, D.G., Ásgeirsdóttir, B.B., Huppert, F.A., Sigfúsdóttir, I.D., Valdimarsdóttir, U.A., Hauksdóttir, A.: How does the economic crisis influence adolescents' happiness? Populationbased surveys in Iceland in 2000-2010. J. Happiness Stud. 17(3), 1219-1234 (2016)

Gundelach, P., Kreiner, S.: Happiness and life satisfaction in advanced European countries. Cross Cult. Res. 38(4), 359-386 (2004)

Hagerty, M.R., Veenhoven, R.: Wealth and happiness revisited-growing national income does go with greater happiness. Soc. Indic. Res. 64(1), 1-27 (2003) 
Haybron, D.: Life satisfaction, ethical reflection, and the science of happiness. J. Happiness Stud. 8(1), 99-138 (2007)

Helliwell, J.F., Huang, H.: New measures of the costs of unemployment: evidence from the subjective well-being of 33 million Americans. Econ. Inq. 52(4), 1485-1502 (2014)

Hills, P., Argyle, M.: The Oxford Happiness Questionnaire: a compact scale for the measurement of psychological well-being. Personal. Individ. Differ. 33(7), 1073-1082 (2002)

Hirschauer, N., Lehberger, M., Musshoff, O.: Happiness and utility in economic thought-or: what can we learn from happiness research for public policy analysis and public policy making? Soc. Indic. Res. 121(3), 647-674 (2015)

Hori, M., Kamo, Y.: Gender differences in happiness: the effects of marriage, social roles, and social support in East Asia. Appl. Res. Qual. Life 13(4), 839-857 (2018)

Howell, R.T., Howell, C.J.: The relation of economic status to subjective well-being in developing countries: a meta-analysis. Psychol. Bull. 134(4), 536 (2008)

Husser, J.A., Fernández, K.E.: We are happier than we realize: underestimation and conflation in measuring happiness. J. Happiness Stud. 19(2), 587-606 (2018)

Iceland, J., Ludwig-Dehm, S.: Black-white differences in happiness, 1972-2014. Soc. Sci. Res. 77, $16-29$ (2019)

Iglesias, E.M., Pena-López, A., Sánchez Santos, J.M.: Bienestar subjetivo, renta y bienes relacionales: los determinantes de la felicidad en España. Revista Internacional de Sociología (RIS) 71(3), 567592 (2013)

Inglehart, R., Klingemann, H.D.: Genes, culture, democracy, and happiness. In: Diener, E., Suh, E.M. (eds.) Culture and Subjective Well-Being, pp. 165-183. The MIT Press, Cambridge (2000)

Joshanloo, M., Rizwan, M., Khilji, I.A., Ferreira, M.C., Poon, W.C., Sundaram, S., Demir, M.: Conceptions of happiness and life satisfaction: an exploratory study in 14 national groups. Personal. Individ. Differ. 102, 145-148 (2016)

Kahneman, D., Schkade, D.A., Fischler, C., Krueger, A.B., Krilla, A.: The structure of well-being in two cities: Life satisfaction and experienced happiness in Columbus, Ohio; and Rennes, France. In: Diener, E., Kahneman, D., Helliwell, J. (eds.) International Differences in Well-Being, pp. 16-33. Oxford University Press, New York (2010)

Kaminitz, S.C.: Happiness studies and the problem of interpersonal comparisons of satisfaction: two histories, three approaches. J. Happiness Stud. 19(2), 423-442 (2018)

Kim, S., Kim, D.: Does government make people happy? Exploring new research directions for government's roles in happiness. J. Happiness Stud. 13(5), 875-899 (2012)

Lane, R.E.: The Loss of Happiness in Market Democracies. Yale University Press, New Haven (2000)

Lawrence, E.M., Rogers, R.G., Zajacova, A., Wadsworth, T.: Marital happiness, marital status, health, and longevity. J. Happiness Stud. 20(5), 1539-1561 (2019)

Layard, R.: Happiness: Lessons from a New Science. Penguin Books, London (2006a)

Layard, R.: Happiness and public policy: a challenge to the profession. Econ. J. 116(510), 24-33 (2006b)

Liu, H., Gao, H., Huang, Q.: Better government, happier residents? Quality of government and life satisfaction in China. Soc. Indic. Res. (2019). https://doi.org/10.1007/s11205-019-02172-2

Loubser, R., Steenekamp, C.: Democracy, well being, and happiness: a 10 nation study. J. Public Aff. 17, 1-12 (2017)

MacKerron, G.: Happiness economics at 35,000 feet. J. Econ. Surv. 26, 705-735 (2012)

MacKerron, G., Mourato, S.: Happiness is greater in natural environments. Glob. Environ. Change 23(5), 9921000 (2013)

Maridal, J.H., Palich, L., Morgan, G., Gardner, S., McKinney, J., Bolbocean, C.: Wellbeing indices: a comprehensive inventory of standards and a review of current comparative measures. Ecol. Econ. 149, 1-11 (2018)

Marinić, M., Brkljačić, T.: Love over gold-the correlation of happiness level with some life satisfaction factors between persons with and without physical disability. J. Dev. Phys. Disabil. 20(6), 527-540 (2008)

Mikucka, M., Sarracino, F., Dubrow, J.K.: When does economic growth improve life satisfaction? Multilevel analysis of the roles of social trust and income inequality in 46 countries, 1981-2012. World Dev. 93, 447-459 (2017)

Mookerjee, R., Beron, K.: Gender, religion and happiness. J. Socio Econ. 34(5), 674-685 (2005)

Myers, D.G., Diener, E.: Who is happy? Psychol. Sci. 6(1), 10-19 (1995)

$\mathrm{Ng}$, Y.K.: Happiness surveys: some comparability issues and an exploratory survey based on just perceivable increments. Soc. Indic. Res. 38(1), 1-27 (1996)

Ng, Y.K., Ho, L.S.: Happiness and Public Policy: Theory, Case Studies and Implications. Palgrave Macmillan, London (2006)

Ngamaba, K.H., Soni, D.: Are happiness and life satisfaction different across religious groups? Exploring determinants of happiness and life satisfaction. J. Relig. Health 57(6), 2118-2139 (2017). https://doi. org/10.1007/s10943-017-0481-2 
Noll, H.H.: Subjective social indicators: benefits and limitations for policy making — an introduction to this special issue. Soc. Indic. Res. 114(1), 1-11 (2013)

Nunally, J.C.: Psychometric Theory. McGraw-Hill, New York (1978)

Núñez-Barriopedro, E., Ravina-Ripoll, R., Ahumada-Tello, E.: Análisis de la situación actual de la felicidad corporativa de los millennials en España, desde el barómetro del Centro de Investigaciones Sociológicas. Revista Académica ECO 18, 1-22 (2018a)

Núñez-Barriopedro, E., Ravina-Ripoll, R., Ahumada-Tello, E.: El impacto del crecimiento económico y empresarial en la felicidad social de la población española. In: Hernández G. de Velazco, JJ, Romero Marín, L.C. (eds.) Perspectivas en Ciencias Jurídicas y Políticas sobre la participación ciudadana, paz, bienestar y felicidad social siglo XXI, Colombia, Barranquilla: Educosta SAS. 190-210 (2018b)

Otis, N.: Subjective well-being in China: associations with absolute, relative, and perceived economic circumstances. Soc. Indic. Res. 132(2), 885-905 (2017)

Ott, J.C.: Government and happiness in 130 nations: good governance fosters higher level and more equality of happiness. Soc. Indic. Res. 102(1), 3-22 (2011)

Pacek, A., Radcliff, B., Brockway, M.: Well-being and the democratic state: how the public sector promotes human happiness. Soc. Indic. Res. 143(3), 1147-1159 (2019)

Park, N., Peterson, C., Ruch, W.: Orientations to happiness and life satisfaction in twenty-seven nations. J. Posit. Psychol. 4(4), 273-279 (2009)

Pavot, W., Diener, E.: The affective and cognitive context of self-reported measures of subjective well-being. Soc. Indic. Res. 28(1), 1-20 (1993)

Peiró, A.: Condiciones socioeconómicas y felicidad de los españoles. Información Comercial Española, ICE: Revista de economía 816, 179-194 (2004)

Peiró, A.: Happiness, satisfaction and socio-economic conditions some international evidence. J. Socio Econ. 35, 348-365 (2006)

Peterson, C., Park, N., Seligman, M.E.: Orientations to happiness and life satisfaction: the full life versus the empty life. In: Delle Fave, A. (ed.) The Exploration of Happiness: Present and Future Perspective, pp. 161-173. Springer, Dordrecht (2013)

Portela Maseda, M., Neira Gómez, I.: Capital social y bienestar subjetivo. Un análisis para España considerando sus regiones. J. Reg. Res. 23, 5-27 (2012)

Proctor, C., Linley, P.A., Maltby, J.: Very happy youths: benefits of very high life satisfaction among adolescents. Soc. Indic. Res. 98(3), 519-532 (2010)

Radcliff, B.: Politics, markets, and life satisfaction: the political economy of human happiness. Am. Polit. Sci. Rev. 95(4), 939-952 (2001)

Ravina-Ripoll, R., Núñez-Barriopedro, E., Evans, R.D., Ahumada-Tello, E.: Employee happiness in the industry 4.0 era: insights from the Spanish industrial sector. In: 2019 IEEE Technology \& Engineering Management Conference (TEMSCON). IEEE, pp. 1-5 (2019)

Ravina-Ripoll, R., Villena-Manzanares, F., Gutiérrez-Montoya, A.G.: A theoretical review to improve outcomes of innovation in enterprises from the perspective of happiness management. Retos 7(14), 113-129 (2017)

Ravina-Ripoll, R., Galiano-Coronil, A., Tobar-Pesantez, L., et al.: Claves para un desarrollo sostenible La creatividad y el happiness management como portafolio de la innovación tecnológica, empresarial y marketing social. Editorial Comares, Granada (2018)

Ringle, C. M., Wende, S., Becker, J.M.: SmartPLS 3. Boenningstedt: SmartPLS GmbH (2015). http://www. smartpls.com. Accessed 5 Mar 2019

Rojas, M. (ed.): Handbook of happiness research in Latin America. Springer, New York (2016)

Ruprah, I.J., Luengas, P.: Monetary policy and happiness: preferences over inflation and unemployment in Latin America. J. Socio Econ. 40(1), 59-66 (2011)

Salas-Vallina, A., Alegre, J., Guerrero, R.F.: Happiness at work in knowledge-intensive contexts: opening the research agenda. Eur. Res. Manag. Bus. Econ. (2018). https://doi.org/10.1016/j.iedeen.2018.05.003

Selim, S.: Satisfacción con la vida y felicidad en Turquía. Soc. Indic. Res. 88(3), 531-562 (2008)

Seung, M.P.: Social policy and late-life happiness: the impact of the basic old-age pension on the happiness of older people in South Korea. Qual. Ageing Older Adults 19(1), 3-13 (2018)

Shin, J.E.: You are my happiness: socially enriched happiness belief predicts life satisfaction, especially among the poor. Cognit. Emot. 33(8), 1702-1708 (2019). https://doi.org/10.1080/02699931.2019.1591343

Stadelmann-Steffen, I., Vatter, A.: Does satisfaction with democracy really increase happiness? Direct democracy and individual satisfaction in Switzerland. Polit. Behav. 34(3), 535-559 (2012)

Stanca, L.: The geography of economics and happiness: spatial patterns in the effects of economic conditions on well-being. Soc. Indic. Res. 99(1), 115-133 (2010)

Tella, R.D., MacCulloch, R.J., Oswald, A.J.: The macroeconomics of happiness. Rev. Econ. Stat. 85(4), 809827 (2003)

Tsou, M.W., Liu, J.T.: Happiness and domain satisfaction in Taiwan. J. Happiness Stud. 2(3), 269-288 (2001) 
Van Praag, B.M., Van Praag, B., Ferrer-i-Carbonell, A.: Happiness Quantified: A Satisfaction Calculus Approach. Oxford University Press, New York (2004)

Veenhoven, R.: Advances in understanding happiness. Revue québécoise de psychologie 18(2), 29-74 (1997)

Veenhoven, R.: Happiness: Also known as "life satisfaction" and "subjective well-being". In: Land, K.C., Michalos, A.C., Sirgy, M.J. (eds.) Handbook of Social Indicators and Quality of Life Research, pp. 63-77. Springer, Dordrech (2012)

Waite, L.J., Lehrer, E.L.: The benefits from marriage and religion in the United States: a comparative analysis. Popul. Dev. Rev. 29(2), 255-275 (2003)

Williams, L.J., Vandenberg, R.J., Edwards, J.R.: Structural equation modeling in management research: a guide for improved analysis. Acad. Manag. Ann 3(1), 543-604 (2009)

$\mathrm{Wu}, \mathrm{Y} ., \mathrm{Zhu}, \mathrm{J} .:$ When are people unhappy? Corruption experience, environment, and life satisfaction in Mainland China. J. Happiness Stud. 17(3), 1125-1147 (2016)

Zweig, J.S.: Are women happier than men? Evidence from the Gallup World Poll. J. Happiness Stud. 16(2), 515-541 (2015)

Publisher's Note Springer Nature remains neutral with regard to jurisdictional claims in published maps and institutional affiliations. 